\title{
DIAGNOSTYKA I LECZENIE NADCIŚNIENIA INDUKOWANEGO CIAZŻA JAKO ELEMENT PROFILAKTYKI OKOŁOPORODOWEJ
}

\author{
DIAGNOSIS AND TREATMENT OF PREGNANCYIINDUCED HYPERTENSION AS A COMPONENT \\ OF PERINATAL PROPHYLAXIS
}

\author{
Anna Michalik, Marta Hajduk, Jolanta Olszewska, Agnieszka Czerwińska-Osipiak \\ Zakład Pielęgniarstwa Położniczo-Ginekologicznego \\ Gdański Uniwersytet Medyczny
}

DOI: https://doi.org/10.20883/pielpol.2017.41

\section{STRESZCZENIE}

Nadciśnienie indukowane ciążą (NIC) jest jedną z najczęstszych patologii okresu okołoporodowego oraz jedną z głównych przyczyn umieralności matek, płodów oraz noworodków. Częstość występowania NIC ocenia się na 3-10\% ciężarnych, a u 15-25\% tej grupy rozwija się stan przedrzucawkowy. Oszacowano, iż 18\% zgonów wśród ciężarnych i położnic wiąże się z NIC i jego powikłaniami, zwłaszcza z rozsianym wykrzepianiem wewnątrznaczyniowym (DIC) [1]. Dodatkowo NIC wiąże się ze zwiększonym ryzykiem powikłań perinatologicznych: porodem przedwczesnym i niską masą urodzeniową. Powikłania te mają długoterminowe skutki dla dziecka i rodziny.

NIC jest to stan podwyższonego ciśnienia tętniczego (powyżej 140/90 mmHg), pojawiający się de novo po 20. tygodniu ciąży (t.c.) i ustępujący po porodzie. Według klasyfikacji z 2007 r., ustalonej przez European Society of Cardiology (ESC) i European Society of Hypertension (ESH), wyróżnia się nadciśnienie przewlekłe, nadciśnienie indukowane ciążą, stan przedrzucawkowy, zespół HELLP oraz nadciśnienie indukowane ciążą nakładające się na nadciśnienie przewlekłe. W etiologii opisywany jest współudział czynników genetycznych, środowiskowych, immunologicznych i metabolicznych. Ponieważ wieloczynnikowa patogeneza NIC oraz stanu przedrzucawkowego nie jest całkowicie poznana, pełne zapobieganie oraz przewidywanie wystąpienia choroby nie jest możliwe. Profilaktyka wtórna skupia się na zapobieganiu powikłaniom u matek (np.: rzucawka) oraz płodów (np.: wcześniactwo).

Przebyty stan przedrzucawkowy koreluje z podwyższonymi wskaźnikami zapadalności na choroby układu sercowo-naczyniowego oraz metaboliczne w kolejnych ciążach i późniejszym okresie życia. Konieczne jest przeprowadzenie w tej grupie pacjentek edukacji na temat stylu życia oraz wdrożenia działań diagnostyczno-leczniczych [1].

Celem pracy jest przedstawienie głównych założeń w postępowaniu diagnostycznym, edukacyjnym i leczniczym NIC oraz stanu przedrzucawkowego, co może stanowić swoiste kompendium dla praktyków i teoretyków opieki położniczej. Minimalizowanie skutków powikłań NIC, z uwagi na częstość występowania schorzenia, jest jednym z głównych założeń w profilaktyce okołoporodowej [4] i profilaktyce chorób układu sercowo-naczyniowego.

SŁOWA KLUCZOWE: nadciśnienie indukowane ciążą, profilaktyka okołoporodowa.

\begin{abstract}
Pregnancy-induced hypertension (PIH) is one of the most common perinatal pathologies and a leading cause of maternal, fetal and neonatal mortality. Prevalence of PIH is estimated at $3-10 \%$ of all pregnancies, and $15-25 \%$ of women with this condition may eventually develop preeclampsia. Mortality of women in pregnancy and puerperium due to $\mathrm{PIH}$ and its complications, especially disseminated intravascular coagulation (DIC), is estimated at $18 \%$ [1]. Moreover, PIH is associated with increased risk of perinatal complications: preterm birth and low birth weight. These complications may have long-term consequences for both the children and their family members.

$\mathrm{PIH}$ is defined as the development of new hypertension (arterial blood pressure greater than $140 / 90 \mathrm{mmHg}$ ) after 20 weeks of gestation with subsequent normalization after birth. According to 2007 European Society of Cardiology (ESC) and European Society of Hypertension (ESH) classification, hypertensive disorders during pregnancy include chronic hypertension, pregnancyinduced hypertension, preeclampsia, HELLP syndrome and PIH superimposed on chronic hypertension. Etiology of hypertension involves genetic, environmental, immune and metabolic factors. Since the multifactorial pathogenesis of PIH and preeclampsia is still not fully understood, this condition can be neither fully prevented nor predicted. Secondary prophylaxis is aimed primarily at the prevention of maternal (e.g. eclampsia) and fetal complications (e.g. prematurity).

History of preeclampsia is associated with higher incidence of cardiovascular and metabolic diseases in future pregnancies and later in life. Therefore, patients from this group need education regarding lifestyle and implementation of a diagnostic-therapeutic intervention [1].

The aim of this paper is to review the principles of diagnostic, educational and therapeutic approach to $\mathrm{PIH}$ and preeclampsia, and may constitute a kind of compendium for practitioners and theoreticians of obstetrical care. Due to high incidence of $\mathrm{PIH}$, neutralization of the impact of its complications is a principal component of both perinatal [4] and in cardiovascular prevention.
\end{abstract}

KEYWORDS: pregnancy-induced hypertension, perinatal prophylaxis. 


\section{Wstęp}

Nadciśnienie indukowane ciążą (NIC) to jedno z głównych powikłań, które mogą wystąpić w czasie jej trwania. Etiopatogeneza schorzenia jest złożona. Częstość występowania NIC ocenia się na 3-10\% ciężarnych. U $15-25 \%$ tej grupy rozwinie się stan przedrzucawkowy. Stan przedrzucawkowy dotyczy od 2 do $7 \%$ zdrowych pierwiastek, 14\% kobiet w ciąży bliźniaczej i 18\% ciężarnych, które przebyły to schorzenie w poprzedniej ciąży. Według Światowej Organizacji Zdrowia nadciśnienie stanowi jedną z głównych przyczyn zgonów okołoporodowych matek na świecie: szacuje się, iż ok. $20 \%$ zgonów wśród ciężarnych i położnic wiąże się z NIC i jego powikłaniami, zwłaszcza z rozsianym wykrzepianiem wewnątrznaczyniowym (DIC). [2] Dodatkowo NIC koreluje ze zwiększonym ryzykiem powikłań perinatologicznych: porodem przedwczesnym i niską masą urodzeniową płodu (poniżej 10 percentyla). Według danych polskich w latach 2007-09 z przyczyn bezpośrednio związanych z NIC oraz stanem przedrzucawkowym u matki odnotowano 54 zgony okołoporodowe płodów i noworodków [3]. Następstwa porodów przedwczesnych i wcześniactwa są jednymi z głównych przyczyn zaburzeń w dalszym okresie życia dziecka. Ponieważ wieloczynnikowa patogeneza NIC oraz stanu przedrzucawkowego nie jest całkowicie poznana, pełne zapobieganie oraz przewidywanie wystąpienia choroby nie jest możliwe. Profilaktyka wtórna skupia się na zapobieganiu powikłaniom u matek (np.: zespół DIC) oraz płodów (np.: wcześniactwo).

Celem pracy jest przedstawienie głównych założeń w postępowaniu diagnostycznym, edukacyjnym i leczniczym NIC oraz stanu przedrzucawkowego, co może stanowić swoiste kompendium dla praktyków i teoretyków opieki położniczej w zakresie profilaktyki. Minimalizowanie skutków powikłań NIC, z uwagi na częstość występowania schorzenia, jest jednym z głównych założeń w profilaktyce okołoporodowej. Wytyczne dotyczące postępowania zostały zawarte w standardzie opieki okołoporodowej dotyczącym niepowodzeń położniczych oraz ciąży powikłanej, ogłoszonym jako Rozporządzenie Ministra Zdrowia z dnia 9 listopada 2015 r. [4]. Dokument zaczął obowiązywać w czerwcu 2016 roku. Efektywność tych działań bezpośrednio przekłada się na ocenę jakości opieki okołoporodowej.

\section{Definicja nadciśnienia indukowanego ciążą (NIC)}

Klasyfikacja nadciśnienia w ciąży jest rozbudowana. Istnieje wiele podziałów, starających się w sposób właściwy ująć korelacje pomiędzy nadciśnieniem pierwotnym a wtórnym, istniejącym przed ciążą i powodowanym ciążą. Aktualnie obowiązuje podział na: nadciśnienie tętnicze występujące przed ciążą (przewlekłe), nadciśnienie tętnicze indukowane ciążą (stan podwyższonego ciśnienia $\geqslant 140 / 90 \mathrm{mmHg}$, który pojawia się po 20. t.c. i po 42. dniu od urodzeniu dziecka ustępuje; przebiega bez obecności białka w moczu, obserwuje się nieprawidłową perfuzję narządów), stan przedrzucawkowy (stan podwyższonego ciśnienia $\geqslant 140 / 90 \mathrm{mmHg}$ oraz białkomocz $\geqslant 0,3 \mathrm{~g} / / / 24 \mathrm{~h}$ ), ciężki stan przedrzucawkowy (stan podwyższonego ciśnienia skurczowego $\geqslant 160 \mathrm{mmHg}$ lub rozkurczowego $\geqslant 110 \mathrm{mmHg}$ oraz białkomocz $>2 \mathrm{~g} /$ 1/24h, z towarzyszącymi objawami zaburzenia funkcji innych narządów i wewnątrzmacicznym zahamowaniem wzrostu płodu) [1].

Nadciśnienie tętnicze można również podzielić według stopnia zaawansowania. Wyróżniamy trzy stopnie: nadciśnienie łagodne, ciężkie i umiarkowane. W tabeli 1 przedstawiono szczegółową klasyfikację.

Tabela 1. Definicje i klasyfikacja nadciśnienia tętniczego w zależności od wartości ciśnienia tętniczego (wg ESH/ESC 2007)

Table 1. Definition and classification of hypertension depended on blood pressure value (ESH/ESC 2007)

\begin{tabular}{|c|c|c|c|}
\hline & $\begin{array}{c}\text { Ciśnienie } \\
\text { skurczowe/ } \\
\text { systolic } \\
\text { pressure [mm Hg]/ }\end{array}$ & & $\begin{array}{c}\text { Ciśnienie } \\
\text { rozkurczowe/ } \\
\text { diastolic } \\
\text { pressure }[\mathrm{mm} \mathrm{Hg}]\end{array}$ \\
\hline Wzorcowe/optimal & $<120$ & $\mathrm{i} /$ and & $<80$ \\
\hline Prawidłowe/normal & $120-129$ & i (lub)/and (or) & $80-84$ \\
\hline $\begin{array}{l}\text { Wysokie, dopuszczalne/ } \\
\text { high normal }\end{array}$ & $130-139$ & i (lub)/and (or) & $85-89$ \\
\hline $\begin{array}{l}\text { Stopień łagodny/ } \\
\text { grade } 1 \text { hypertension }\end{array}$ & $140-159$ & i (lub)/and (or) & $90-99$ \\
\hline $\begin{array}{l}\text { Stopień umiarkowany/ } \\
\text { grade } 2 \text { hypertension }\end{array}$ & $160-179$ & i (lub)/and (or) & $100-109$ \\
\hline $\begin{array}{c}\text { Stopień ciężki/ } \\
\text { grade } 3 \text { hypertension }\end{array}$ & $\geqslant 180$ & i (lub)/and (or) & $\geqslant 110$ \\
\hline $\begin{array}{l}\text { Nadciśnienie skurczowe } \\
\text { izolowane/isolated } \\
\text { systolic hypertension }\end{array}$ & $\geqslant 140$ & i (lub)/and (or) & $<90$ \\
\hline
\end{tabular}

Źródło: The Task Force for the Management of Arterial Hypertension of the European Society of Hypertension (ESH) and the European Society of Cardiology (ESC), w: Guidelines for the Management of Arterial Hypertension, “Journal of Hypertension”, 2007, nr 25, s. 1105-1187.

\section{Etiopatogeneza nadciśnienia indukowanego ciążą}

Etiologia NIC nie jest jednoznaczna. Aktualnie za najbardziej prawdopodobną uznaje się teorię dotyczącą nieprawidłowego zagnieżdżenia się trofoblastu (zaburzenia przepływu krwi w kosmówce/łożysku), co korelowane jest $z$ wczesnym wystąpieniem objawów choroby. Z późnym wystąpieniem NIC oraz stanu przedrzucawkowego wiąże się obecność czynników metabolicznych (insulinooporność, cukrzyca, dyslipidemia, otyłość) lub 
sercowo-naczyniowych, (nadciśnienie tętnicze), predysponujących do uszkodzenia śródbłonka i nadmiernej odpowiedzi immunologicznej organizmu [1,5].

Stwierdzono, iż wiek ciężarnej bezpośrednio koreluje z zapadalnością: częściej problem dotyczy ciężarnych z grupy wiekowej 30-39 lat i poniżej 18 r.ż., w porównaniu z grupą 18-29 lat. Obecnie częstość występowania przewlekłego nadciśnienia tętniczego wynosi od 0,6 do $2 \%$ u kobiet w przedziale wiekowym 18-29 lat, a od 4,6 do 22,3\% w wieku 30-39 lat [5]. Wzrastający wiek ciężarnych bezpośrednio koreluje ze wskaźnikami zapadalności na tę chorobę. Bardzo trudno ustalić częstość występowania nadciśnienia przewlekłego w ciąży, ponieważ objawy pojawiają się stopniowo, zwłaszcza w początkowym okresie rozwoju choroby, nie manifestują się dolegliwościami, dlatego też choroba ta może pozostać nierozpoznana, zwłaszcza jeśli nie ma okresowych kontroli.

W grupie otyłych ciężarnych odsetek zapadalności na NIC i stan przedrzucawkowy jest wyższy. U pacjentów z otyłością stwierdzono znaczące zmiany w składzie bakteryjnej flory jelitowej, jak również utrzymującą się trwale miernie nasiloną reakcję zapalną organizmu. Udowodniono, iż fakt ten dodatnio koreluje z wysokim ciśnieniem tętniczym w ciąży w grupie pacjentek ze znaczną nadwagą i otyłością. Obfitość bakterii z rodzaju Odoribacter we florze jelitowej korelowała z niższym ciśnieniem krwi oraz niższym poziomem aktywowania stanu zapalnego w grupie ciężarnych z nadwagą i otyłych w 16 t.c. Postawiono tezę, iż suplementacja flory jelitowej u ciężarnych z tych grup ryzyka może przyczynić się do utrzymania prawidłowych wartości ciśnienia krwi [7].

Ryzyko rozwinięcia się przewlekłego nadciśnienia tętniczego po przebyciu NIC wynosi pomiędzy 2, 3 i 11 lat, natomiast prawdopodobieństwo rozwinięcia się cukrzycy typu 2 jest większe o 1,8\% [8].

Kobiety, które przebyły stan przedrzucawkowy lub rzucawkę, są dwukrotnie bardziej narażone na udar, mają znacząco podwyższone ryzyko ujawnienia się arytmii i niewydolności serca. Ryzyko to zwielokrotnia się, gdy NIC indukował dalsze powikłania dla płodu w postaci porodu przedwczesnego lub niskiej masy urodzeniowej. Dodatkowo u tych pacjentek zaobserwowano dziesięciokrotnie wyższe ryzyko rozwinięcia się chorób nerek. Uważa się, iż okres poporodowy w tej grupie kobiet jest bardzo dobrą okazją do modyfikacji zwyczajów związanych z trybem życia, nadwagą/otyłością, wczesnej diagnostyki przewlekłego nadciśnienia tętniczego, cukrzycy i interwencji w celu zmniejszenia zapadalności na choroby układu sercowo-naczyniowego $[8,9]$.

\section{Kryteria diagnostyczne nadciśnienia indukowanego ciążą}

Najprostszy algorytm diagnostyczny NIC zakłada, że chorobę można rozpoznać w oparciu o wartość oznaczonego ciśnienia tętniczego, mierzoną dwukrotnie w przeciągu sześciu godzin. Wynik, który jest większy lub równy 140/90 mmHg, lub podwyższenie wartości wyjściowej ciśnienia skurczowego o co najmniej $30 \mathrm{mmHg}$, a rozkurczowego o $15 \mathrm{mmHg}$, uprawniają do postawienia diagnozy. Pomiar ciśnienia tętniczego powinien być wykonywany w pozycji lewobocznej leżącej, bądź półleżącej, po ok. 5 minutach spoczynku, z ramieniem leżącym na wysokości serca. Miejscem pomiaru powinno być ramię, na którym stwierdzono wyższe wartości ciśnienia. Ważny jest również odpowiedni dobór mankietu, tak aby był 1,5 raza dłuższy od obwodu ramienia, lub - gdy jego obwód jest większy niż $35 \mathrm{~cm}$ - należy użyć mankietu udowego. Aby uniknąć błędu w pomiarach, należy uśrednić dwa kolejne odczyty, ze względu na zmienność ciśnienia tętniczego [10].

U kobiet ciężarnych wartość ciśnienia rozkurczowego stwierdza się na podstawie $\mathrm{V}$ fazy tonów Korotkowa bądź w oparciu o IV fazę, w sytuacji gdy zaniknięcie tonów wysłuchuje się przy ciśnieniu na poziomie $0 \mathrm{mmHg}$.

W diagnostyce NIC, a także w trakcie obserwacji postępów leczenia, bardzo przydatną metodą jest automatyczne, całodobowe monitorowanie ciśnienia tętniczego w warunkach ambulatoryjnych (ABPM). Wyniki pomiarów ciśnienia tętniczego uzyskane tą metodą, w zestawieniu z jednorazowymi pomiarami, dokładniej pokazują ryzyko powstania białkomoczu, poza tym w oparciu o te wyniki można precyzyjniej określić ryzyko porodu przedwczesnego, rozwiązania ciąży przez cięcie cesarskie, niskiej masy urodzeniowej, a także konieczności leczenia noworodka na oddziale neonatologicznym.

W diagnostyce nadciśnienia tętniczego w ciąży i różnicowaniu postaci tej choroby niezbędna jest obserwacja parametrów hematologicznych za pomocą badań laboratoryjnych [5]:

- utrata białka - jeśli w moczu obserwujemy białko, wówczas rozpoznaje się stan przedrzucawkowy, chyba że zostanie postawione inne rozpoznanie w oparciu o dodatkowe badania; utrata białka powyżej 2 g/dobę wymaga dokładnej obserwacji, natomiast utrata białka większa niż $3 \mathrm{~g} /$ dobę skłania do rozważenia indukcji porodu;

- albuminy w surowicy - stężenie albumin w surowicy krwi może być zmniejszone wskutek utraty z łożyska naczyniowego naczyń włosowatych, 
obniżenia syntezy w wątrobie oraz przy niewielkich zmianach w wartościach białka ogólnego;

- hemoglobina i hematokryt - hemoliza jest czynnikiem obniżającym stężenie hemoglobiny i hematokrytu, ale tylko hemokoncentracja potwierdza rozpoznanie nadciśnienia generowanego ciążą;

- rozmaz krwi obwodowej - niedokrwistość hemolityczna mikroangiopatyczna potwierdza nadciśnienie indukowane ciążą nawet przy podwyższeniu ciśnienia tętniczego w sposób umiarkowany;

- $\quad$ płytki krwi - zmniejszone stężenie płytek krwi jest wykładnikiem ciężkiej postaci nadciśnienia;

- transaminazy w surowicy krwi - wzrastające stężenie transaminaz potwierdza ciężką postać nadciśnienia wraz z uszkodzeniem wątroby; konieczna jest obserwacja ciężarnej w stronę wystąpienia zespołu HELLP;

- dehydrogenaza kwasu mlekowego - podwyższone stężenie dehydrogenazy świadczy o hemolizie i uszkodzeniu wątroby, a co za tym idzie jest wykładnikiem nadciśnienia o ciężkiej postaci;

- $\quad k w a s$ moczowy w surowicy krwi - zwiększenie wartości kwasu moczowego ułatwia diagnostykę postaci nadciśnienia i pozwala określić ciężkość choroby;

- kreatynina w surowicy krwi - podwyższone wartości (zwłaszcza przy towarzyszącym skąpomoczu) potwierdzają ciężką postać nadciśnienia [5].

\section{Postępowanie lecznicze i profilaktyczne}

Leczenie nadciśnienia indukowanego ciążą obejmuje postępowanie farmakologiczne i niefarmakologiczne oraz zapobieganie wystąpieniu stanu przedrzucawkowego.

Postępowanie niefarmakologiczne opiera się na zwiększonym nadzorze nad ciężarną, czyli regularnych pomiarach ciśnienia tętniczego i analizie badań laboratoryjnych. Zaleca się również ograniczenie wysiłku fizycznego, zarówno zawodowego, jak i domowego, a także częsty odpoczynek na lewym boku, zawsze w pozycji leżącej. Zabrania się spożywania alkoholu i palenia tytoniu. Dieta powinna być lekkostrawna, bogata w białko i substancje odżywcze, mikroelementy oraz witaminy. Nie ma potrzeby ograniczania spożycia soli, gdyż wiąże się to ze zwiększonym ryzykiem hipotensji na skutek zmniejszenia objętości śródnaczyniowej [15]. Obecnie nie wykazuje się żadnego związku pomiędzy wartościami ciśnienia tętniczego w ciąży a doustną podażą chlorku sodu w przeciętnej diecie [12].

Według standardu opieki okołoporodowej w ciąży powikłanej w przypadku stwierdzenia ciśnienia tętniczego krwi powyżej wartości 140/90 mmHg w pierwszym trymestrze ciąży należy skierować ciężarną do II stopnia opieki perinatalnej w celu dalszej diagnostyki. W drugim trymestrze ciąży należy monitorować wartości ciśnienia co najmniej 4 razy dziennie w warunkach domowych, a także wykonać badania biochemiczne krwi i moczu ciężarnej oraz badania ultrasonograficzne płodu, w celu wykluczenia stanu przedrzucawkowego. U pacjentki, u której zidentyfikowano jedynie nadciśnienie ciążowe, należy rozpocząć leczenie hipotensyjne z użyciem metyldopy, utrzymując wartości ciśnienia tętniczego poniżej 150 mmHg ciśnienia skurczowego krwi i 100 mmHg ciśnienia rozkurczowego; przy braku efektu leczenia należy skierować ciężarną do opieki na II poziomie opieki perinatalnej [4].

$\mathrm{Na}$ podstawie dotychczasowych badań nie stwierdzono jednoznacznie korzyści z suplementacji diety wapniem, czy olejami rybimi. Natomiast w nawiązaniu do wytycznych ESH/ESC, w celu prewencji stanu przedrzucawkowego, zaleca się profilaktyczne przyjmowanie kwasu acetylosalicylowego (ASA) w dawce 75-150 mg dziennie. ASA hamuje powstawanie wolnych rodników tlenowych oraz nadtlenków lipidowych, które mają znaczenie w etiopatogenezie stanu przedrzucawkowego. Dlatego też zalecenie to dotyczy kobiet, u których stwierdzono duże ryzyko wystąpienia stanu przedrzucawkowego, czyli z rozpoznanym NT we wcześniejszej ciąży, z NT przewlekłym, z rumieniowatym toczniem układowym, chorobą nerek, cukrzycą 1 i 2 typu, a także zespołem antyfosfolipidowym. Stosowanie profilaktycznej dawki ASA u kobiet z tych grup ryzyka zmniejszyło śmiertelność okołoporodową noworodków, częstość preeklampsji i porodów przedwczesnych oraz przyczyniło się do zwiększenia masy ciała noworodków [13].

Profilaktyka z zastosowaniem ASA powinna być rozpoczęta jeszcze przed 16 t.c., ale nie wcześniej niż po 12 t.c., ze względu na możliwe powikłania. Profilaktyka może być zachowana aż do porodu. Przeciwskazaniem do stosowania ASA jest krwawienie z przewodu pokarmowego [13].

Do leków I rzutu w ciąży, oprócz metylodopy, zalicza się również labetalol, który bardzo skutecznie obniża wyższe wartości ciśnienia tętniczego. Leki II rzutu to antagoniści wapnia i beta-blokery. Dihydralazyna, ze względu na zwiększoną częstość objawów ubocznych występujących okołoporodowo, zaliczana jest do leków III rzutu. Stosowana jest w przypadku ciężkiej postaci NIC, ciężkiego przewlekłego nadciśnienia w ciąży, połogu, stanie przedrzucawkowym i rzucawce. Lekami bezwzględnie zakazanymi podczas ciąży i karmienia piersią są inhibitory konwertazy angiotensyny oraz blokery receptora angiotensynowego. W leczeniu nadciśnienia należy pamiętać, że nie wolno obniżać gwałtownie ciśnienia, ponieważ prowadzi to do spadku perfuzji w macicy oraz łożysku, a także niedokrwienia w obrębie narządów wewnętrznych i OUN [5, 11, 13]. 
Leki moczopędne często są stosowane podczas ciąży w przewlekłej postaci nadciśnienia tętniczego, jako kontynuacja leczenia sprzed okresu ciąży. Postępowanie to jest wskazane w przypadku sodozależnego nadciśnienia przewlekłego, ponieważ zmniejsza to ryzyko powikłań metabolicznych i elektrolitowych. Należy jednak zmniejszyć dawkę leku. Z leków moczopędnych dopuszczalne w ciąży są diuretyki tiazydowe. Nie powinno się natomiast rozpoczynać terapii tymi lekami w przypadku nadciśnienia tętniczego generowanego ciążą, w stanie przedrzucawkowym, ponieważ leki te powodują zmniejszony przepływ łożyskowy, czego skutkiem może być ograniczenie wewnątrzmacicznego wzrostu płodu [5, 11, 13].

Przed zastosowaniem leczenia farmakologicznego przy nadciśnieniu tętniczym indukowanym ciążą, przewlekłym nadciśnieniu, stanie przedrzucawkowym, rzucawce czy zespole HELLP należy rozważyć wskazania i korzyści leczenia. Bardzo potrzebny okazuje się algorytm postępowania [4].

Opieka ambulatoryjna nad tą grupą pacjentek możliwa jest w lekkich postaciach NIC lub gdy uzyska się pożądaną stabilizację ciśnień za pomocą podawanych leków oraz jeśli życiu ciężarnej i płodu nie zagraża niebezpieczeństwo. Częstość wizyt powinna być ustalona raz na dwa tygodnie lub częściej.

\section{Podsumowanie}

Każdy rodzaj nadciśnienia wikłającego ciążę jest poważnym czynnikiem ryzyka dla matki i płodu. Standardy opieki okołoporodowej określają zasady postępowania diagnostyczno-terapeutycznego w przypadku wystąpienia tego schorzenia. Wytyczne oparte na zasadach medycyny opartej na dowodach naukowych (EBM) i kliniczne doświadczenie praktyków mają bezpośredni wpływ na jakość leczenia i minimalizację ryzyka trwałych powikłań. Nie można zapominać, iż NIC w obecnej ciąży jest poważnym czynnikiem ryzyka również dla przyszłych ciąż i późniejszego zdrowia kobiety. Kobiety, które przebyły w ciąży różnego pochodzenia nadciśnienie, szczególnie w połączeniu z zaburzeniami wzrostu wewnątrzmacicznego płodu, znacząco częściej zapadają na choroby układu sercowo-naczyniowego. Udowodniono, iż modyfikacja stylu życia i eliminacja pozaciążowych czynników ryzyka rozwinięcia się nadciśnienia i innych chorób układu sercowo-naczyniowego znacząco zmniejsza stopień zapadalności w tej grupie [8, 14].

Bardzo istotne jest, aby już w opiece przedkoncepcyjnej wyłonić indywidualne bądź rodzinne czynniki ryzyka NIC. Do chorób zwiększających ryzyko wystąpienia NIC należy cukrzyca, choroby nerek, przewlekłe nadciśnienie tętnicze, otyłość, choroby tarczycy, choro- by zakaźne, autoimmunologiczne i choroby serca. Pacjentkę z nadciśnieniem tętniczym należy objąć opieką przedkoncepcyjną co najmniej trzy miesiące przed planowanym zajściem w ciążę [15]. W obu przypadkach jest to kluczowy etap w minimalizowaniu dalszych powikłań nadciśnienia w okresie okołourodzeniowym: niewydolności jednostki maciczno-łożyskowej, przedwczesnego oddzielenia łożyska, zaburzeń we wzroście wewnątrzmacicznym płodu, stanu przedrzucawkowego i rzucawki oraz porodu przedwczesnego i wcześniactwa. Ponadto niekontrolowane lub nieleczone nadciśnienie tętnicze jest przyczyną bezpośredniego zagrożenia życia matki.

W okresie przedkoncepcyjnym u pacjentek z przewlekłym nadciśnieniem tętniczym trzeba zaplanować zmiany w dotychczasowym trybie życia, które dotyczą zmian w zakresie aktywności domowej i zawodowej, nabycia zwyczaju samoobserwacji, wprowadzenia pełnowartościowej diety, redukcji masy ciała i umiarkowanej aktywności fizycznej. Palenie papierosów (czynne lub bierne) dodatkowo zwiększa ryzyko hipotrofii płodu i przedwczesnego oddzielenia łożyska. Jeśli założymy, że u $20 \%$ ciężarnych z NIC rozwija się wewnątrzmaciczne zahamowanie wzrostu płodu, to dodatkowe palenie czyni ryzyko powikłań noworodkowych wybitnie znaczącym. Wynika to ze wspólnego mechanizmu powstawania tych patologii, jakim jest zaburzenie w perfuzji łożyska, które rozwija się już na etapie trofoblastu.

W celu podniesienia jakości opieki okołoporodowej oraz zmniejszenia stopnia zachorowania na choroby, których wystąpienie koreluje z przebytym NIC, należy traktować kobiety z tej grupy jako szczególnie narażone na zachorowanie. Ryzyko wystąpienia chorób układu sercowo-naczyniowego, cukrzycy i innych może być modulowane nie tylko poprzez wczesną diagnozę i leczenie, ale przede wszystkim przez działania profilaktyczne. Edukacja na temat środowiskowych czynników ryzyka jest szczególnie ważna w tej grupie pacjentek.

\section{Piśmiennictwo}

1. Steegers EA, von Dadelszen P, Duvekot JJ, Pijnenborg R. Preeclampsia. Lancet 2010; 376: 631-644.

2. WHO, UNICEF, UNFPA, World Bank Group and the United Nations Population Division; Trends in maternal mortality: 1990 to 2015; estimates by WHO, UNICEF, UNFPA, World Bank Group and the United Nations Population Division http://www.who.int/reproductivehealth/publications/monitoring/maternal-mortality-2015/en/

3. Troszyński M, Maciejewski T, Wilczyńska A, Banach B, Przyczyny martwych urodzeń i zgonów noworodków w Polsce w latach 2007-2009 Ginekol Pol. 2011, 82, 598-601

4. Rozporządzenie Ministra Zdrowia z dnia 9 listopada 2015 r. w sprawie standardów postępowania medycznego przy udzielaniu świadczeń zdrowotnych w dziedzinie położnictwa i ginekologii z zakresu okołoporodowej opieki położniczo-ginekologicznej, sprawowanej nad kobietą w okresie 
ciąży, porodu, połogu, w przypadkach występowania określonych powikłań oraz opieki nad kobietą w sytuacji niepowodzeń położniczych (Dz.U. z 2015 r., poz. 2007)

5. Bręborowicz GH, Tykarski A, Szczepaniak-Chicheł L, Kornacki J. Nadciśnienie tętnicze u kobiet w ciąży, w: Bręborowicz GH (red.). Ciąża wysokiego ryzyka, Poznań: Ośrodek Wydawnictw Naukowych; 2010, 971-1011.

6. The Task Force for the Management of Arterial Hypertension of the European Society of Hypertension (ESH) and the European Society of Cardiology (ESC), w: Guidelines for the Management of Arterial Hypertension, J Hypertens 2007, nr 25. 1105-1187

7. Gomez-Arango L, Barrett H, McIntyre D, Callaway L, Morrison M, Nitert M, for the SPRING Trial Group, Increased Systolic and Diastolic Blood Pressure Is Associated With Altered Gut Microbiota Composition and Butyrate Production in Early Pregnancy, Hypertension 2016, Published online before print August 15, 2016, doi: 10.1161/ HYPERTENSIONAHA.116.07910

8. Ray JG, Vermeulen M, Schull M, Redelmeier D, Cardiovascular health after maternal placental syndromes (CHAMPS): population-based retrospective cohort study, the Lancet, Volume 366, No. 9499, 1797-1803, 19 November 2005

9. Alvarez-Alvarez B, Martell-Claros N, Abad-Cardiel M, García-Donaire JA. Hypertensive disorders during pregnancy: Cardiovascular long-term outcomes. Hipertens Riesgo Vasc. 2016 Jul 6. pii: S1889-1837(16)30029-0. doi: 10.1016/j.hipert.2016.06.002.

10. Mancia G, Fagard R, Narkiewicz K. 2013 ESH/ESC Guidenes for the management of arterial hypertension: The Task Force for the management of arterial hypertension of the European Society of Hypertension (ESH) and the European Society of Cardiology (ESC), J Hypertens 2013, 31, $1281-1357$

11. Woźniewicz M. Zespół HELLP ( Hemolysis, Elevated Liver enzymes, Low Platelet count), W: Dębski R. Stany nagłe. Położnictwo i ginekologia, Warszawa: Medical Tribune Polska; 2012. 296-298.
12. Inoue M, Tsuchihashi T, Hasuo T, Ogawa M, Tominaga M, Arakawa K, Oishi E, Sakata S, Ohtsubo T, Matsumura K, Kitazono T, Salt Intake, Home Blood Pressure, and Perinatal Outcome in Pregnant Women; Circulation Journal, accepted July 24, 2016; released online August 29, 2016 Time forprimary review: 45 days;

13. Widecka K, Grodzicki T, Narkiewicz K, i wsp. Zasady postępowania w nadciśnieniu tętniczym - 2011 rok. Wytyczne Polskiego Towarzystwa Nadciśnienia Tętniczego, Nadciśnienie Tętnicze, 2011, 15, 55-82

14. Cain MA, Salemi JL, Tanner JP, Kirby RS, Salihu HM, Louis $\mathrm{JM}$, Pregnancy as a window to future health: maternal placental syndromes and short-term cardiovascular outcomes. Am J Obstet Gynecol. 2016 Jun 2. pii: S0002-9378(16)30267-8. doi: 10.1016/j.ajog.2016.05.047. [Epub ahead of print]

15. Stadnicka G, Iwanowicz-Palus G, Pilewska-Kozak AB. Planowanie rodziny z uwzględnieniem czynników ryzyka, w: Stadnicka G (red.). Opieka przedkoncepcyjna. Warszawa: PZWL; 2009, 125-149

Artykuł przyjęty do redakcji: 04.07.2016

Artykuł przyjęty do publikacji: 04.11.2016

Źródło finansowania: Praca nie jest finansowana z żadnego źródła. Konflikt interesów: Autorzy deklarują brak konfliktu interesów.

\section{Adres do korespondencji:}

Anna Michalak

ul. Dębinki 7

80-211 Gdańsk

tel.: 583491968

e-mail: aniamichalik@gumed.edu.pl

Zakład Pielęgniarstwa Położniczo - Ginekologicznego

Gdański Uniwersytet Medyczny 